\title{
Summary
}

Tetiana Obikhod. Historical aspects and prospects of legal development of society.

The current stage of development of our society is characterized by low civic activism, disrespect for the laws and, as a result, low legal culture and legal illiteracy. Therefore, the formation of a legal culture, the study of the origins of its occurrence and its implementation in society is one of the most important tasks of our time.

Legal development and regulation of the public life of mankind took place in several stages. We will only touch on some of them:

- The laws of Hammurabi or the Codex of Hammurabi (1750s BC);

- Cyrus Cylinder (539 BC);

- The Bible;

- Magna Carta (1215);

- DECLARATION OF THE RIGHTS of man and citizen (adopted by the deputies of the General States on August 24, 1789);

- The Declaration of Independence, according to which the American colonies withdrew from the British Empire in 1776.

The Christian model of social relations is clearly reflected in literature. The books of Thomas More "Utopia", John Locke "The Experience of Human Understanding" and Hobbes "Leviathan" are vivid artistic demonstrations of the desired social structure.

On the other hand, faith in the best of mankind is realized at the level of perfection of an individual person. Voltaire's Candide, which says that everyone should "cultivate their own garden," concentrates the author's social optimism, his faith in the "eternal tree of life". B. Spinoza in his major philosophical work Ethics proclaimed the famous "formula of freedom": freedom is a conscious necessity.

Summarizing the above, several stages of the legal development of human society can be noted: 1) the union between God and man; 2) legal laws appear as connecting links between the will of God and human will (M. Luther); 3) the autonomy of legal relations, their independence from the spiritual authorities (the era of the Reformation); 4) the fundamental gap between the religious normative system and secular social principles, the attitude to religious faith as an outdated form of social life (Russo, Voltaire, Didro, Holbach, Helvetius, etc.); 5) the union of ideas of personal responsibility and moral autonomy, the conformity of Christian values to spiritual and moral standards.

The legal consciousness of a person in modern society is heterogeneous, contradictory, and deformed. Legal nihilism and legal arbitrariness flourish in people. The reason for this is the low economic development of society and, as a result, low legal and moral culture. The pronounced primacy of materialism with complete indifference to man as a person is the main problem of our time. To enhance the legal culture necessary:

1. The Ministry of Culture and the Ministry of Education and Science, Youth and Sports should implement measures for the rehabilitation of young; 2. The Ministry of Justice and the Ministry of Internal Affairs of Ukraine shall conduct general legal training of the population of Ukraine; 3. Encourage broadcasters and print media to introduce more educational and educational programs; 4. Involve church-goers with television and radio broadcasts with interesting stories from both historical and religious sources and topics of current problems.

Key words: law, legal culture, human rights, legal nihilism, legal values.

DOI: 10.36695/2219-5521.2.2019.05

УДК 348+340.132.6(37) “00/03"

Ю.В. ЦВЄТКОВА

Юліанна Володимирівна Цветкова, кандидат юридичних наук, доцент, доцент юридичного фракультету Київського Національного університету імені Тараса Шевченка*

ORCID: 0000-0001-7557-7048

\section{НОРМАТИВНО-ПРАВОВІ АКТИ, ЩО РЕГУЛЮВАЛИ РЕЛІГІЙНІ ПРАВОВІДНОСИНИ У РИМІ I-IV СТ. ТА ЇХ ЗАСТОСУВАННЯ НА ПРАКТИЦІ ДЛЯ РИМСЬКИХ ФЕДЕРАТІВ}

Період з I по IV ст. є етапом не тільки швидкого територіального зростання Римської держави, а й централізації її влади та набуття правотворчих функцій принцепсами та домінусами. У таких умовах на її території неминуче мали відбуватися синкретичні асиміляційні процеси для населення ії федеративних суб'єктів. Свобода віросповідання як одне із беззастережних автономічних прав федератів та демонстрація релігійної толерантності Риму у республіканських період теж мала піддатися цим тенденціям. Проте порівняння законодавства принципів з цього предмета та його застосування на практиці демонструє досить неоднозначну картину.

Нормативно-правові акти, видані вищими римськими державними органами у період з I по IV ст., як правило, виходили з авторства принцепсів та Сенату. Їх текст зберігся при їх включенні у пізніші збірки рим-

() Ю.В. Цвєткова, 2019

* Yulianna Tsvietkova, Ph.D. in Law, Associate professor, Associate professor of Taras Shevchenko National University of Kyiv 
ського права (наприклад, у Кодекс Феодосія чи Corpus Juris Civilis). Деякі акти відомі нам у переказі через наративні джерела, зокрема багато таких описів міститься у Светонія 1 , Тацита ${ }^{2}$, дещо згадується у Прокопія Кесарійського ${ }^{3}$, Касія Діона ${ }^{4}$

Різні аспекти релігійного законодавства Риму розглядалися у працях таких відомих дослідників, як А. Волчков, П. Джонс, Ф. Зелинський, О. де Казанове, А. Каргальцев, П. Лашкарев, Я. Межирицький, Н. Пенник, О. Петречко, Й. Рупке, Е. Штаерман та інші. Проте більшість цих праць є історичними, а отже, вони присвячені скоріше історичним подіям, навіть і пов'язаним з релігійними відносинами. Існуючі аналізи правового регулювання релігійних правовідносин зосереджуються, як правило, або на території самого міста Рима, або прив'язані до християнства, яке якраз поширюються. У жодному разі не применшуючи значення цих досліджень, слід зазначити, що додаткове порівняння змісту нормативно-правових актів принцепсів (імператорів) із релігійних питань 3 подальшою їх реалізацією на місцях може продемонструвати нові грані римської правової традиції релігійної толерантності.

Метою статті є аналіз нормативно-правових актів вищих правотворчих органів Риму з I по IV ст., присвячених регулюванню неримських релігій та простеження подальшого правозастосування цих норм на територіях федератів Римської держави.

Едикти принцепсів були об'єктивними джерелами, що формували систему римського публічного права, в тому числі й регулювання релігійних правовідносин. Стверджені Сенатом, або одноосібні, вони могли поширюватися як на всю імперію, так і тільки на Італію.

Першим із таких нормативно-правових актів досліджуваного періоду, що були видані главою держави та врегульовували свободу віросповідання федератів, була заборона Гаєм Юлієм Цезарем проводити ритуали друїдів. Ця заборона була видана у I ст. до н.е., але ііі дія повною мірою поширилася на імперію в I ст. н.е. Акт стосувався здебільшого територій проживання кельтів, тобто сучасних Франції, Іспанії, Великобританії, територій держав Бенілюксу тощо. Офіційним обгрунтуванням прийняття такого закону стало проведення людських жертвопринесень, в яких Цезар звинуватив кельтів 5 . Однак тут не можна не враховувати й політичний фактор: іспанські походи та галльська війна Цезаря підкорила Риму цілу низку незалежних до того кельтських племен, а ті племена, які до цього були у складі Римської держави, зазнали збільшення римського впливу, багато з них втратили статус foederi та перетворилися на провінції. Друїдизм був не тільки об'єднуючою релігією кельтського суспільства, а й складною організацією, друїди часто могли виконувати функцію правителів та користувалися величезним авторитетом у народі 6 . Заборона їхньої діяльності та подальші гоніння запобігали появі серед незадоволених Римом кельтських племен організованого руху опору, суттєво зменшуючи ризик повстання. Усі наступні принцепси підтримували політику Цезаря в цьому питанні.

Гай Октавіан Август своїм едиктом забороняє культ Ісіди в Римі7, що є продовженням вже існуючої традиції обмеження проникнення культів інших племен в Рим, але не перешкоджає їх сповіданню на союзних територіях, в даному випадку, у Єгипті, який увійшов до складу Римської держави за Юлія Цезаря. Так само як і у випадку аналогічної заборони культу Діонису, цей акт Августа викликав обурення серед мешканців

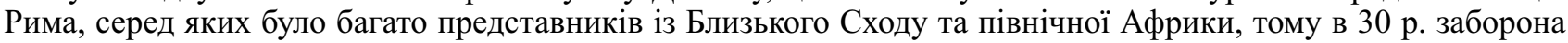
була скасована та навіть побудовано храм Ісіди на Марсовому полі ${ }^{8}$.

Радикальними поглядами у релігійній сфері відрізнявся Тиберій. Його едикти категорично забороняли чужоземні обряди на території Риму, причому особливо суворо ця заборона стосувалася єгипетських та іудейських таїн9 ${ }^{9}$ Своїм едиктом Тиберій наказав вислати до Сардінії 4000 іудеїв, а іншим прихильникам східних релігій залишити територію Італії10. Щодо поширення цих заборон на федератів, ніяких вказівок немає, однак виходячи з того, що на Близькому Сході та в Єгипті обидві згадані в едиктах Тиберія релігії в період його правління сповідуються вільно й про гоніння не згадується, можна зробити висновок про адресність цієї заборони виключно на землі метрополії. Однак релігії італіків та греків в його законодавстві описується в позитивному сенсі: не приймається едикт про відведення річок навколо Риму, що під час періодичних повеней завдають місту значних матеріальних втрат, із низкою аргументів, серед яких $є$ такий, що Рим не може не вбачати звичаї та вірування своїх старовинних італійських союзників, ритуальні місця яких постраждають через гідротехнічні роботи ${ }^{11}$. Під керівництвом Тиберія Сенат розбирає справи про надання притулку у грецьких храмах, складаючи вичерпаний перелік храмів 3 таким правом12. Це ледь не єдиний випадок втручання римлян в релігійні справи федератів на території останніх, але й тут Тацит підкреслює, що едикти Тиберія та Сенату регулюють не ритуал та вірування, а світські обставини, адже храми, беззастережно даючи притулок злочинцям, порушують принцип обов’язковості покарань та «...приховують під благочестям честолюбність...»13.

Гнучкість поглядів на свободу віросповідання федератів спостерігається й у Клавдія. 3 одного боку, своїм едиктом 54 р. він категорично забороняє друїдизм на всій території, підвладній Риму14, та спеціальним наказом зобов'язує римських посадовців та військових знищувати друїдські вівтарі й гаї15, а 3 іншого боку, не втручається в релігійні свободи не тільки федератів, а й навіть провінцій Греції та Сходу. Окремим едиктом він забезпечує права і свободи євреїв, які проживають у метрополії, надаючи їм право проводити служіння та обмежуючи таким чином дію едикту Тиберія. Особливу увагу в своїх нормах Клавдій приділяє релігії етрусків, яку він не сповідував, але поважав за точні передбачення гаруспіків. Це унікальне явище для ставлення римлян до релігій федератів реалізується в доповіді Клавдія Сенату про створення державним коштом спеціальної колегії, що має вивчати та підтримувати етруський культ, адже раніше «... ці обряди зберігали за своїм бажанням етруська знать, а тепер це робиться гірше...» ${ }^{16}$. Едикт Клавдія підтримує і Нерон ${ }^{17}$, 
який підтримував культи Італії та Греції, але при цьому схвалював судові справи по обвинуваченню римлян у дотриманні «чужих вірувань», як правило, східних ${ }^{18}$. Одним із зазначених «східних» вірувань вважалося християнство, яке на той час ототожнювалося з іудаїзмом та розглядалося як його гілка. Із суб'єктів римської федерації масовий статус іудаїзм мав у Іудеї, а християнство к II ст. стало достатньо популярним у Єгипті, Кафагені та Нумідії, проте ніде не набуло статусу релігії більшості.

Найвідомішим актом щодо релігійних питань імператора Траяна є едикт 99 р. про заборону таємних товариств. Його текст традиційно вважають зверненим проти християн ${ }^{19}$, проте, на нашу думку, він $є$ набагато ширшим. Зрештою, слід усвідомлювати, що Римська імперія цього часу - величезна держава зі складним територіально-адміністративним устроєм, яка включила до свого складу багато територій всупереч волі їхнього населення. Заборона таємних товариств тут може і повинна мати політичний характер. Звісно, важко заперечувати релігійну складову, адже ця сфера традиційно залишалася римлянами на розсуд місцевого населення та територіальних аутентичних органів, отже, в очах цезарів поєднати релігійну та таємну антиримську організацію було достатньо логічно.

Певну дискусію серед дослідників римського права викликає законодавча діяльність династії Северів. Існує інформація про суворий едикт Септімія Севера (хоча його текст не знайдено) щодо заборони християнського та іудейського прозелітизму 20 . Не враховуючи того, що сам факт видання едикту викликав гоніння на християн в Сгипті та Північній Африці, текст едикту за його реконструкціями на підставі праць наративних джерел його сучасників був не таким вже й жорстким. Переслідуванню піддавалися тільки новонавернені, ті ж, хто сповідував обидві релігії, раніше не обмежувалися в своїх ритуалах. Залишається відкритим і санкція, передбачена едиктом, адже одні джерела вказують, що це були штрафи та ганебні акції, а інші - що санкції були фізичні 21 . Ми підтримуємо думку дослідників, згідно з якою відповідне законодавство Севера могло бути прив'язано скоріше до Іудеї, яка тільки що піднімала повстання проти Риму через релігійну причину22. Християни ж потрапили в комплект до іудеїв через деякі свої радикальні секти, що були популярні у Єгипті та Північній Африці. Зайвим підтвердженням риси політичності, а не релігійної нетолерантності цього едикту є той факт, що ані в діях, ані в законодавстві Септімія Севера не зустрічається інших випадків репресій за ознакою віросповідання.

Вибірковість релігійних заборон характеризує правління Діоклетіана. Він помірковано ставився до політеїстичних культів, не обмежуючи їх сповідання ані в Римі, ані на периферії23, але при цьому категорично обмежував поширення дуалістичних культів, вбачаючи в них загрозу імперії. Його едикт «Про чаклунів та маніхеїв» 287 р. викликав гоніння не тільки на зороастрійців, але й на християн, які напряму в його тексті не згадувалися. Цікаво зауважити, що в подальшому цей едикт потрапив в християнське Сollatio під титулом Кодексу Грегоріана (Coll 15.3) 24 та використовувався вже християнською церквою для боротьби 3 іновірцями.

Релігійні едикти імператорів початку IV ст. здебільшого присвячені пом'якшенням ставлення Риму до християнства та поширюються на всю територію імперії. Зазначене пом'якшення було викликано, з одного боку, швидким зростанням кількостей християнських громад, а, з іншого боку, діяльністю єпископа Тертуліана (III ст.), який, користуючись своїм авторитетом у християн, зміг домовитися з римською адміністрацією через пошук компромісів між християнськими догмами та римським правом. До низки таких едиктів слід включити едикт Галерія 311 р., що дозволяв сповідувати християнство мешканцям імперії, та загальновідомий Міланський едикт 312 р. Костянтина. Наступний едикт Костянтина «Про помилковість політеїзму» 323 р. закликав населення навертатися у християнство, але при цьому не обмежувати свободу віросповідання язичників ${ }^{25}$, що, по суті, підготовлювало грунт для зміни державної релігії, проте на виходячи за межі традиційної римської толерантності в цьому питанні.

Нормативно-правові акти будь-якої держави становлять іiі систему права, але, як відомо, навіть при наявності авторитарно-тоталітарного режиму та жорсткої вертикалі влади (чого в Римі цього періоду не було) дуже складно забезпечити їхнє беззастережне виконання при відсутності підтримки у пересічного населення. Як вбачається при аналізі письмових свідчень та матеріальних джерел, навіть у публічно-правовій сфері свобода віросповідання федератів реалізовувалася значно більше, ніж це передбачало центральне законодавство метрополії.

Відстежуючи посилання на дії посадових осіб Риму, які є представниками публічно-правових відносин на територіях суб'єктів федерації, можна побачити, що не тільки місцеве населення продовжувало сповідувати власні культи, які відрізнялися від центрально-державного, а й самі посадові особи брали в них активну участь, часто ігноруючи існуючи нормативно-правові заборони.

Так, Август, вихваляючи свої вчинки, порівнює їх з іудейськими обрядами ${ }^{26}$, а відвідавши Єгипет, відмовляється взяти участь у частуванні Апіса не тому, що це не відповідає його релігійним поглядам чи посаді, а тому, що йому особисто нецікаво 27.

Починаючи з Юлія Цезаря, правителі Риму намагалися залучити підтримку своїй діяльності у тількино приєднаній Малій Азії. Побоюючись спиратися на царів, влада яких з приходом Риму обмежилася, вони всіляко співпрацювали із жрецтвом місцевих культів, що природно можливо тільки при лояльному ставленні до самих культів. Зокрема, існують свідчення про дарування імператорами місцевим храмам земель та просування на високі жрецькі посади своїх ставлеників 28.

У Галлії місцевий фламін Августа та Марса Сульпіцій додатково виконує функції жерця бога Молтіна та називає себе гутуатром - друїдським жерцем ${ }^{29}$, не зважаючи на заборони друїдського культу Цезарем та 
Тиберієм. Дедикант Тибурній у своїх мемуарах зазначає, що під час служби в Аквитанії брав участь у місцевому культі богині Онуави та продовжує іії вшановувати й після від'їздуз3.

Небіж Тиберія Германик по дорозі до Азії публічно висловлює бажання відвідати в Самофракії таїнства місцевого старовинного культу Кабирів, який тут вільно сповідується ${ }^{31}$.

Корисним для встановлення рівня свободи віросповідання федератів Риму в цей період $\epsilon$ похід в Месопотамію Вітеллія. Тацит зазначає, що військо Вітеллія складається з різних військових частин: римських та союзницьких. Перед переправою через річку Вітеллій для надихання війська особисто проводить два жертвопринесення - одне за римським обрядом (бика та баранів), а інше за союзницьким (коня) ${ }^{32}$. Такий вчинок Вітеллія не тільки демонструє наявність у союзників власних, відмінних від римських культів, а й визнання та повагу римських посадових осіб до них.

Участь у релігійних культах федератів при перебуванні на їхній території беруть і самі імператори. Віспасіан в Іудеї приносить жертви філістимлянським богам, а в Єгипті - Серапісу33, Отон та пізніше Тит беруть участь у містеріях Ісіди та Апіса в Сгипті ${ }^{34}$, поважливе ставлення до єгипетських культів та участь у жертвопринесенні Серапісу демонстрував Септімій Север 35 . Діоклетіан, відомий своїм радикальним ставленням до дуалістичних культів, вільно спілкується з друїдськими жерцями, діяльність яких була заборонена низкою едиктів його попередників ${ }^{36}$. Ще з більшою повагою він ставиться до політеїстичних культів федератів: для покращення стосунків із новатами на півдні Єгипту Діоклетіан розбудовує храмовий комплекс у Філах із жертовниками римським та місцевим богам і запрошує туди римських та новатських жерців, сподіваючись на встановлення дружніх стосунків між народами ${ }^{37}$.

Послугами германських жерців-гадателів користується Доміціан ${ }^{38}$, він же відкрито зазначає, що його брат Флавій Климент сповідує іудаїзм, а єдиним обмеженням для іудеїв за його правління є стягування спеціального податкуз3. Навіть сам імператор Галерій, який вже схилявся до християнства, висловлював побоювання богів своєї батьківщини Дакії, у яких немає вівтарів у Римі ${ }^{40}$. Порівнюючи з періодом республіки, фактів проявів публічної поваги до пантеонів своїх федератів, римські правителі демонструють значно більше. Здається, що саме цей час є піком римської релігійної толерантності.

Нижчі посадовці демонструють повагу до федератських релігій не менш яскраво, ніж правителі імперії. У вотивних надписах місцевим богам Нижньої Німеччини та Британії постійно згадуються не тільки представники місцевої адміністрації та солдат, а й посадовці римляни та римляни-командуючі розквартированих легіонів ${ }^{41}$.

Для неримлянина, який отримує державну посаду, зберігається можливість сповідувати релігію власного народу: так, консул Медавр із народу далматів за часів Марка Аврелія, перебуваючи на службі в Ламбезисі (сучасний Алжир), встановлює у місцевому храмі статую бога-лара свого народу42. Цілі збройні частини римської армії, розквартировані у Британії, влаштовують державним коштом святкування германського релігійного свята Sonnenwende, в якому бере участь і їхнє військове керівництво ${ }^{43}$.

Фактичним матеріальним свідченням свободи віросповідання федератів у I-V ст. є храми, капища та молитовні місця неримських релігій, що розбудовувалися чи вільно функціонували на території суб'єктів. Існування та розбудова таких місць, проведення обрядів (якщо вони не домашні чи таємні) можливі тільки з дозволу римських посадових осіб, які виконували свої обов'язки на даній території.

Так, за часів правління Діоклетіана у Британії відновлюються кельтські храми, заборонені попередніми імператорами, причому участь у їхній розбудові беруть римські офіційні особи: презид Першої Британії відновлює статую та жертовник у Дуроконавії, що фіксується на пам'ятній дошці в храмі ${ }^{4}$. Включно до IV ст. у Глостерширі функціонує величезний кельтський храмовий комплекс 45 .

Тиберій Клавдій Профес, член імператорської родини, призначений посадовцем до едуїв та лінгонів, не тільки суміщає свої посадові обов'язки римського громадянина з посадами у місцевому самоврядуванні, а й будує портік у місцевому храмі Моритазга ${ }^{46}$.

У Придунавії та Карінітії масово будуються храми Латобія, символами якого є човни та вода (його інколи ототожнюють із Марсом), богині матері народу Норейї та бога вогню Седата ${ }^{47}$.

Наприкінці I ст. н.е. у дунайських провінціях масово з'являються храми сирійським богам, що можна пояснити розселенням там сирійських найманців, тут же активно і досить масово сповідується культ Діонісу, взагалі заборонений в Італії під страхом смертної кари ${ }^{48}$. Для сирійців, які переселилися в Рим за наказом Марка Аврелія будують храм Митри на Ватикані49.

Ще цікавішим $є$ храмово-вівтарний комплекс на півдні Іспанії, описаний Страбоном у I ст. (який діяв до VII ст.), до якого місцеві жерці забороняли пускати римлян ${ }^{50}$. Іспанія з I по IV ст. взагалі переживає період «кельтського відродження», що супроводжується розквітом місцевих культів ${ }^{51}, 3$ якими не може боротися навіть християнство, що стрімко набирає популярності на сході імперії.

Залишається відкритим сповідання на території Італії неримських латинських культів: храмові комплекси місцевих богів Пренесту та Тибуру змагаються в архітектурі з римськими ${ }^{52}$, за часів Тиберія реконструюється храм Мефітісу в Луканії53.

Не зустрічається інформації щодо обмежень сповідання в азійських та африканських провінціях місцевих культів. Абсолютно вільно сповідується власна релігія в Єгипті, хоча в самому Римі щодо культу Ісіди існують обмеження ${ }^{4}$. Розквітає Пальмира $з$ ії власними унікальними синкретичними культами Бели, Арсу, Баалшамину та ін. ${ }^{55}$, а культ бога-сонця Малої Азії стає настільки популярним, що його навіть пробують запровадити в Римі імператори Каракалла та Геліогабал Северіани. 
Гоніння відбуваються тільки в Іудеї на іудаїзм, але, як вже зазначалося, вони мають політичний характер і є скоріше винятком. Після едиктів Траяна та Септімія Севера під репресії потрапляють християни Єгипту та Північної Африки, проте сам Тертуліан зазначає, що організація цих гонінь та їх розмах залежав тільки від ініціатив місцевої влади ${ }^{56}$. Але не слід забувати, що місцева влада являла собою не тільки римську адміністрацією, а й місцеві органи самоврядування, а судова гілка влади, наприклад, була повністю сформована з місцевих мешканців. За таких передумов залишається відкритим питання, хто демонстрував описану релігійну нетолерантність до християн - призначені Римом чиновники чи місцеві авторитети, які могли бути незадоволені поширенням на своїх теренах чужої релігії або хотіли наповнити місцевий бюджет та власні скарбниці з конфіскованого у християн майна. Додатковим чинником, що додає вагомості цим аргументам, може бути те, що в інших провінціях імперії про такі антихристиянські репресії в цей час не згадується ${ }^{57}$.

Аб̆слютно автономною в цей період є релігійна політика германських племен федератів, що оселяються на центральноєвропейській частині Римської держави. Тацит описує релігійний побут племен свевів та бастарнів із сповіданням їх власної релігії та обрядами божеств Алки, які не мають аналогів у римській традиції 58 .

Таким чином, можемо підсумувати, що в період з I по IV ст. римське законодавство регулювало релігійні відносини неримського населення досить мало та казусно. Акти заборони сповідувати певну релігію часто реалізовувалися тільки в центральних районах держави та мовчазно ігнорувалися на периферії. Свобода віросповідання федератів Римської держави, не зважаючи на загальні доцентрові тенденції в сфері її адміністративного управління, в цілому гарантувалася. Римляни, в тому числі посадові особи, не тільки дозволяли сповідання місцевих культів, а й самі могли стати їх дедикантами, що категорично не схвалювалося у республіканському періоді. Наявні релігійні репресії у цей період були поодинокими випадками та обгрунтовувалися не доктринально-філософськими чи божественними чинниками, а прагматичною й раціональною державно-суспільною необхідністю.

1 Светоний Гай Транквилл. Жизнь двенадцати Цезарей. Москва: Азбука, 2015. 480 с.

2 Тацит Корнелій. Аннали. Київ: Український письменник, 2013. 700 с.

3 Прокопий Кесарийский. Война с персами. Война с вандалами. Тайная история / пер. А.А. Чекаловой. Москва: Наука, 1993. $570 \mathrm{c}$.

4 Кассий Дион Коккейан. Римская история. Книги LI-LXIII / под ред. А.В. Махлаюка. Санкт-Петербург: Нестор-История, 2014. 680 с

5 Записки Юлия Цезаря и его продолжателей о Галльской войне, о Гражданской войне, об Александрийской войне, об Африканской войне / пер. М.М. Покровского. Москва-Ленинград: Изд-во АН СССР. 1948. 560 с.

${ }^{6}$ Green Miranda J. Exploring the world of the druids. London: Thames \& Hudson. 2005. P. 24.

7 Межерицкий Я.Ю. «Республиканская монархия»: метаморфозы идеологии и политики императора Августа. Москва Калуга: КГПУ, 1994. С. 216; Кассий Дион Коккейан. Римская история. Книги LI-LXIII / под ред. А.В. Махлаюка. Санкт-Петербург: Нестор-История, 2014. 680 с.

8 Пенник Н., Джонс П. История языческой Европы. Москва: Евразия, 2000. 496 с. С. 110.

${ }^{9}$ Светоний Tib. 36.

10 Тацит II. 85.

11 Тацит I 79.

12 Тацит III 60-63.

13 Тацит III 63.

14 Светоний Claud. 25.

15 Тацит XIV 30; Пенник Н., Джонс П. История языческой Европы. Москва: Евразия, 2000. 496 с. С. 160.

16 Тацит XI 16.

17 Тацит XIII 24.

18 Тацит XIII 32.

19 Волчков А.С. Римское законодательство относительно религиозных и профессиональных союзов. Мнемон. 2008 . № 7. C. $321-345$.

20 Петречко О.М. Переслідування християн у добу Септимія Севера (193-211 рр.). Історичний архів. 2012. № 8. С. 57-62; Каргальцев А.В. Религиозная политика Септимия Севера в свете антихристианских гонений. Религия. Церковь. Общество. 2018. № . 7. C. 156-173. doi:10.24411/2308-0698-2018-00009

${ }^{21}$ Каргальцев А.В. Там само. С. 156-159.

22 Каргальцев А.В. Там само. С. 159.

23 Каргальцев А.В. К вопросу о мотивах религиозной политики Диоклетиана. Христианское чтение. 2016. № 5. С. $115-124$.

24 Пенник Н., Джонс П. История языческой Европы. Москва: Евразия, 2000. 496 с. С. 122.

25 Лашкарев П. Отношение Римского государства къ религии вообще и къ христіанству въ особенности. Киев: Тип. С.Г. Еремеева, 1876.148 с. С. $62-63$.

26 Светоний Octav. 76.

27 Светоний Octav. 93.

28 Бибарсова Ю.А. Малоазийские клиенты Цезаря в гражданской войне 49-46 гг. до н. э. Научные ведомости БелГУ. Серия: История. Политология. Экономика. Информатика. 2009. № 1 (56). С. 19-23.

29 Штаерман Е.М. Мораль и религия угнетенных классов Римской империи (Италия и Западные провинции). Москва: Изд-во АН СССР, 1961. 319 с. С. 191.

30 Там само. С. 198.

31 Тацит II. 54. 
32 Тацит VI. 37.

33 Светоний Visp. 5,7.

34 Светоний Oton 12, Titus 5.

35 Каргальцев А.В. К вопросу о мотивах религиозной политики Диоклетиана. Христианское чтение. 2016. № 5 . С. 157.

36 Пенник Н., Джонс П. История языческой Европы. Москва: Евразия, 2000. 496 с. С. 175.

37 Прокопий Кес. Перс I, XIX 31-36.

38 Светоний Domic. 12.

39 Светоний Domic. 12-15.

40 Штаерман Е.М. Мораль и религия угнетенных классов Римской империи (Италия и Западные провинции). Москва:

Изд-во АН СССР, 1961. 319 с. С. 237.

41 Там само. C. 212.

42 Там само. С. 266.

43 Пенник Н., Джонс П. История языческой Европы. Москва: Евразия, 2000. 496 с. С. 225.

44 Штаерман Е.М. Мораль и религия угнетенных классов Римской империи (Италия и Западные провинции). Москва: Изд-во АН СССР, 1961. 319 с. С. 178.

45 Пенник Н., Джонс П. История языческой Европы. Москва: Евразия, 2000. 496 с. С. 155.

46 Штаерман Е.М., С. 190-191.

47 Там само. С. 220.

48 Там само. С. 241.

49 Пенник Н., Джонс П. История языческой Европы. Москва: Евразия, 2000. 496 с. С. 113.

50 Там само. С. 172.

51 Циркин Ю.В. История древней Испании. Санкт-Петербург: Философский ф-т СПб. ГУ, 2011. 432 с.

52 Rupke Jorg Religion in Republican Rome. Philadelphia: University of Pennsilvania. 2012. 328 p. C. 14.

53 Cazanove, de Olivier Some thoughts on the "religious romanisation" of Italy before the Social War. Religion in Archaic and Republican Rome and Italy. Evidence and Experience. Edinburgh: Edinburgh University Press, 2000. P. 71-80.

54 Зелинский Ф.Ф. Соперники християнства. Санкт-Петербург: Алетейя, 1995. 407 с. С. 79.

55 Rupke Jorg, ibid. C. 190-210. Scap. 3-5.

56 Тертуллиан. Апологетик. К Скапуле / пер. А.Ю. Братухина. Санкт-Петербург: Изд-во Олега Абышко, 2005.256 с. ad

57 Каргальцев А.В. Религиозная политика... С. 159-160.

58 Лозинська С.О. Прикордонна політика Римської імперії у центрально-східній Європі (I-III ст. н.е.): дис. ... канд. істор. наук. Львів, 2010. 200 с. С. 113; Тацит Germ. 43.

\section{References:}

Svetonyj, H.T. (2015) Zhyzn’ dvenadtsaty Tsezarej. Moskva: «Azbuka» [in Russian].

Tatsyt Kornelij. (2013) Annaly. Kyev: «Ukrains'kyj pys'mennyk» [in Ukrainian].

Prokopyj Kesaryjskyj. (1993) Vojna s persamy. Vojna s vandalamy. Tajnaia ystoryia. Per. A.A. Chekalovoj. Moskva: «Nauka» [in Russian].

Kassyj Dyon Kokkejan. (2014) Rymskaia ystoryia. Knyhy LI-LXIII. Pod red. A. V. Makhlaiuka. Sankt-Peterburh: Nestor-Ystoryia [in Russian].

Zapysky Yulyia Tsezaria y eho prodolzhatelej o Hall'skoj vojne, o Hrazhdanskoj vojne, ob Aleksandryjskoj vojne, ob Afrykan-

skoj vojne (1948) Per. M.M. Pokrovskoho. Moskva-Lenynhrad: Yzd-vo AN SSSR [in Russian].

Miranda J. Green. (2005) Exploring the world of the druids. London: Thames \& Hudson [in English].

Mezherytskyj, Ya.Yu. (1994) «Respublykanskaia monarkhyia»: metamorfozy ydeolohyy y polytyky ymperatora Avhusta. Moskva-Kaluha: KHPU [in Russian].

Pennyk, N., Dzhons, P. (2000) Ystoryia iazycheskoj Evropy. Moskva: Evrazyia [in Russian].

ian].

Volchkov, A.S. (2008) Rymskoe zakonodatel'stvo otnosytel'no relyhyoznykh y professyonal'nykh soiuzov Mnemon. 7 [in Russ-

Petrechko, O.M. (2012) Peresliduvannia khrystyian u dobu Septymiia Severa (193-211 rr.) Istorychnyj arkhiv. 8 [in Ukrainian]. Karhal'tsev, A.V. (2018) Relyhyoznaia polytyka Septymyia Severa v svete antykhrystyanskykh honenyj. Relyhyia. Tserkov'. Obschestvo. 7. doi:10.24411/2308-0698-2018-00009 [in Russian].

Karhal'tsev, A.V. (2016) K voprosu o motyvakh relyhyoznoj polytyky Dyokletyana. Khrystyanskoe chtenye. 5 [in Russian].

Lashkarev, P. (1876) Otnoshenye Rymskoho hosudarstva k' relyhyy voobsche y k' khrystianstvu v' osobennosty. Kyev: Typ. S.H.

Eremeeva [in Russian].

Bybarsova, Yu.A. (2009) Maloazyjskye klyenty Tsezaria v hrazhdanskoj vojne 49-46 hh. do n. e. Nauchnye vedomosty BelHU.

Seryia: Ystoryia. Polytolohyia. Ekonomyka. Ynformatyka. 1 (56) [in Russian].

Shtaerman, E.M. (1961) Moral' y relyhyia uhnetennykh klassov Rymskoj ymperyy (Ytalyia y Zapadnye provyntsyy). Moskva:

Yzd-vo AN SSSR [in Russian].

Tsyrkyn, Yu.V. (2011) Ystoryia drevnej Yspanyy. Sankt-Peterburh: Fylosofskyj f-t SPb HU [in Russian].

Rupke, Jorg (2012) Religion in Republican Rome. Philadelphia: University of Pennsilvania [in English].

Cazanove, de Olivier (2000) Some thoughts on the "religious romanisation" of Italy before the Social War. Religion in Archaic

and Republican Rome and Italy. Evidence and Experience. Edinburgh: Edinburgh University Press [in English].

Zelynskyj, F.F. (1995) Sopernyky khrystyianstva. Sankt-Peterburh: «Aletejia» [in Russian].

Tertullyan. (2005) Apolohetyk. K Skapule. Per. A. Yu. Bratukhyna. Sankt-Peterburh: Yzdatel'stvo Oleha Abyshko [in Russian].

Lozyns'ka, S.O. (2010) Prykordonna polityka Ryms'koi imperii u tsentral'no-skhidnij Yevropi (I-III st. n.e.). Dys. na zdob. k.i.n.

L'viv [in Ukrainian]. 


\section{Резюме}

Цвєткова Ю.В. Нормативно-правові акти, що регулювали релігійні правовідносини у Римі I-IV ст. та їх застосування на практиці для римських федератів.

Стаття присвячена аналізу правотворчих актів принцепсів та домінусів Римської держави, присвячених регулюванню неримських релігій та простеження подальшого правозастосування цих норм на територіях федератів Римської держави.

Робиться висновок про те, що у період з I по IV ст. римське законодавство регулювало релігійні відносини неримського населення досить мало та казусно. Акти заборони сповідувати певну релігію часто реалізовувалися тільки в центральних районах держави та мовчазно ігнорувалися на периферії. Наявні релігійні репресії у цей період були поодинокими випадками та обгрунтовувалися не доктринально-філософськими чи божественними чинниками, а прагматичною й раціональною державно-суспільною необхідністю.

Ключові слова: свобода віросповідання, законодавство принцепсів, законодавство домінусів.

\section{Резюме}

Цветкова Ю.В. Нормативно-правовые акты, регулирующие религиозные правоотношения в Риме I-IV ст. и их применение на практике для римских федератов.

Статья посвящена анализу актом принцепсов и доминусов Римского государства, посвященных регулированию неримских религий и прослеживанию дальнейшего применения этих норм на территориях федератов Римского государства.

Делается вывод, что в период с I по IV ст. римское законодательство регулировало религиозные отношения неримского населения достаточно мало и казусно. Акты запрета исповедовать определенную религию часто реализовывались только в центральных районах государства и молчаливо игнорировались на периферии. Случавшиеся религиозные репрессии в этот период были одиночными и объяснялись не доктринально-философскими и божественными факторами, а прагматической и рациональной государственно-правовой необходимостью.

Ключевые слова: свобода вероисповедания, законодательство принцепсов, законодательство доминусов.

\section{Summary}

Yulianna Tsvietkova. Normative legal acts regulating religious legal relations in the Roman Empire in I-IV centuries and their practical application towards the Roman foederati.

The article is focused on the analysis of the I-V centuries legal acts of the Roman principes and domini regulating non-Roman religions and further application of these acts at the territories of the Roman Empire's foedereati.

Religious edicts of Gaius Octavianus Augustus, Tiberius, Claudius, Traianus, Septimius Severus, Diocletian, Galerius and Constantine are examined. Prolonged edict of Gaius Julius Caesar's edict "Against druids" is examined also.

The article analyses possible reasons behind the acts based on the social, political, military, and economic situation in the Roman state and taking into account personal views and subjective behavior of the emperors.

Further on the article studies the practice of following the bans embodied in the edicts at the various territories of the Roman state by the high governmental officials, who represented Roman power at the mentioned territories, as well as by the representatives of local state powers and self-government.

This practice has been taking into account the views of the Roman powers on the territory's "safety" or "troublesomeness", amounts of the local cults' followers, religious composition of the local population.

Conclusion is made that during the period of I-IV centuries the Roman laws regulated religious relations amongst non-Roman population occasionally and with no specific significance.

Bans on certain religion were often found to be applied only at the central regions of the state and to be silently ignored at the periferia.

Despite of the general centripetal trends in the sphere of administration the freedom of faith was generally guaranteed to the Roman state's foederati.

In the period of the Empire the Romans, including high officials, not only allowed local cults attendance but could also become a follower themselves, a situation firmly unwelcomed during the Republican period.

Religious repressions of the period of I-IV centuries were occasional and were grounded not on the doctrinal-philosophical or divine reasons but on the pragmatic and realistic state and social necessities.

Key words: Freedom of Faith, legal acts of princepces, legal act of dominuses. 